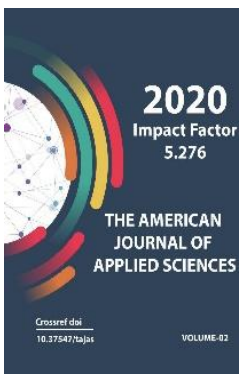

Copyright: Original content from this work may be used under the terms of the creative commons attributes 4.0 licence.

\section{Mice Tourism: Opportunities, Priorities, Problems, Prospects}

\section{Sayyora Safaeva}

PhD, Associate Professor, International Tourism Faculty, Tashkent State University Of Economics, Uzbekistan

\section{Diyora Adilova}

4th Year Student, International Tourism Faculty, Tashkent State University Of Economics, Uzbekistan

\title{
ABSTRACT
}

The MICE sector is one of the most significantly developing tourism industries in recent years. The growth of business tourism strongly affects not only the industry as a whole, but also the economy of the host country. However, with the development and greater popularization of MICE tourism, various difficulties arise. The research work will reveal the main opportunities, prospects and priorities for the development of the MICE tourism industry, as well as analyze the problematic aspects that MICE agencies face when organizing their activities.

\section{KEYWORDS}

MICE industry, specialized agencies, infrastructure, conference halls, material and technical base, service

quality,

high season, catering services

\section{INTRODUCTION}

The term MICE (Meetings, Incentives, Conferences, Events) is widely utilized in international practice to denote four keywords that characterize the field of business travel - meetings, incentives, conferences and

exhibitions. The MICE market is a specialized group tourism niche dedicated to planning, 
booking and promoting events and is a major source of income for the travel industry.

It is customary to distinguish two areas in business tourism: corporate travel industry and the MICE meeting industry. The abbreviation MICE is formed by the initial letters of four English words, which, when deciphered, show the directions of organizing these tours [7]:

1. Meetings (meetings) - negotiations with partners, meetings, trainings and seminars for dealers, and other options for business meetings. The correct organization largely forms the company's image.

2. Incentives (incentives) - incentive tours that are designed to express gratitude to customers, employees and partners. They perfectly motivate the team, strengthen corporate values and have a positive effect on work.

3. Conferences (conferences) - organization of seminars, conferences, trips to exhibitions, for which an effective result is important.

4. Events (exhibitions, events) - organization of offsite corporate events and tours

MICE travel agencies are usually associated with a large number of service providers. Personnel and businesses involved in the MICE market include corporate appointment planners, conference departments at hotels, convention centers or cruise ships, food and beverage managers, logistics firms, private tour operators and transfer companies, travel trade associations, sales managers and others. Agents working in this area must provide a full range of travel services for large and small groups, as well as events of varying duration. Destinations positioned as MICE locations rely on holding events through conference centers and visitors' bureaus.

\section{RESEARCH METHODOLOGY}

Methods of analysis, synthesis and comparative analysis were used throughout the study.

Level of study of the topic

For a large amount of time, the leaders of business tourism were the United States and European countries - Germany, Italy, Czech Republic, Croatia. Now the situation is changing, there is a tendency to expand the geography of countries in which the flows of business tourism are growing. In addition to traditional leaders, China, Thailand, India, Tunisia are becoming attractive for business tourism, Russia is also an active participant in this process.

Tourism, as a sector of the economy, is multifaceted, as it affects almost all spheres of activity, from the transport industry, hotel business to the sphere of culture and education. The tourism industry is constantly evolving, offering all new types and forms of recreation and travel. One of the modern and dynamically developing

types of tourism are considered business or business tourism, which has become the subject of discussion and scientific research relatively recently, over the past few decades. Business tourism demand as an independent

the direction in the market of tourist services began to increase with the development of the economic system in general and business in particular. It is believed that business tourism, in the modern sense, began to develop in the late 40s. XX century, when the first regular flights from Europe to the USA began.

R. Davidson believes that this is one of the oldest forms of tourism, and a person traveled for business purposes, for example, for trade, from the earliest times of the formation of human society [8]. Business meetings, conferences, participation in exhibitions are 
leading on the international market of tourist services in terms of the number of trips made.

According to Suvaryan Arzik M., Saakyan Maria A. and Antamoshkina Elena N. the organizational and economic conditions for doing business presuppose an active exchange of information, the dissemination of modern, innovative technologies, participation in international congresses, seminars, exhibitions, etc. Business tourism contributes to the rapid dissemination and implementation of new ideas in the economy, entering new markets and, in general, the development of scientific and technological progress [9].

\section{ANALYSIS AND RESULTS}

In this regard, it should be noted that outsourcing is a necessary component in the field of conference and exhibition tourism (Figure 1). Outsourcing support is manifested in the transfer of certain functions for creating services to third-party organizations involved in the formation of this type of product (event organizations, air / railway companies, hotels, etc.). Outsourcing companies have a direct impact on the further interaction between MICE-agencies and service providers.

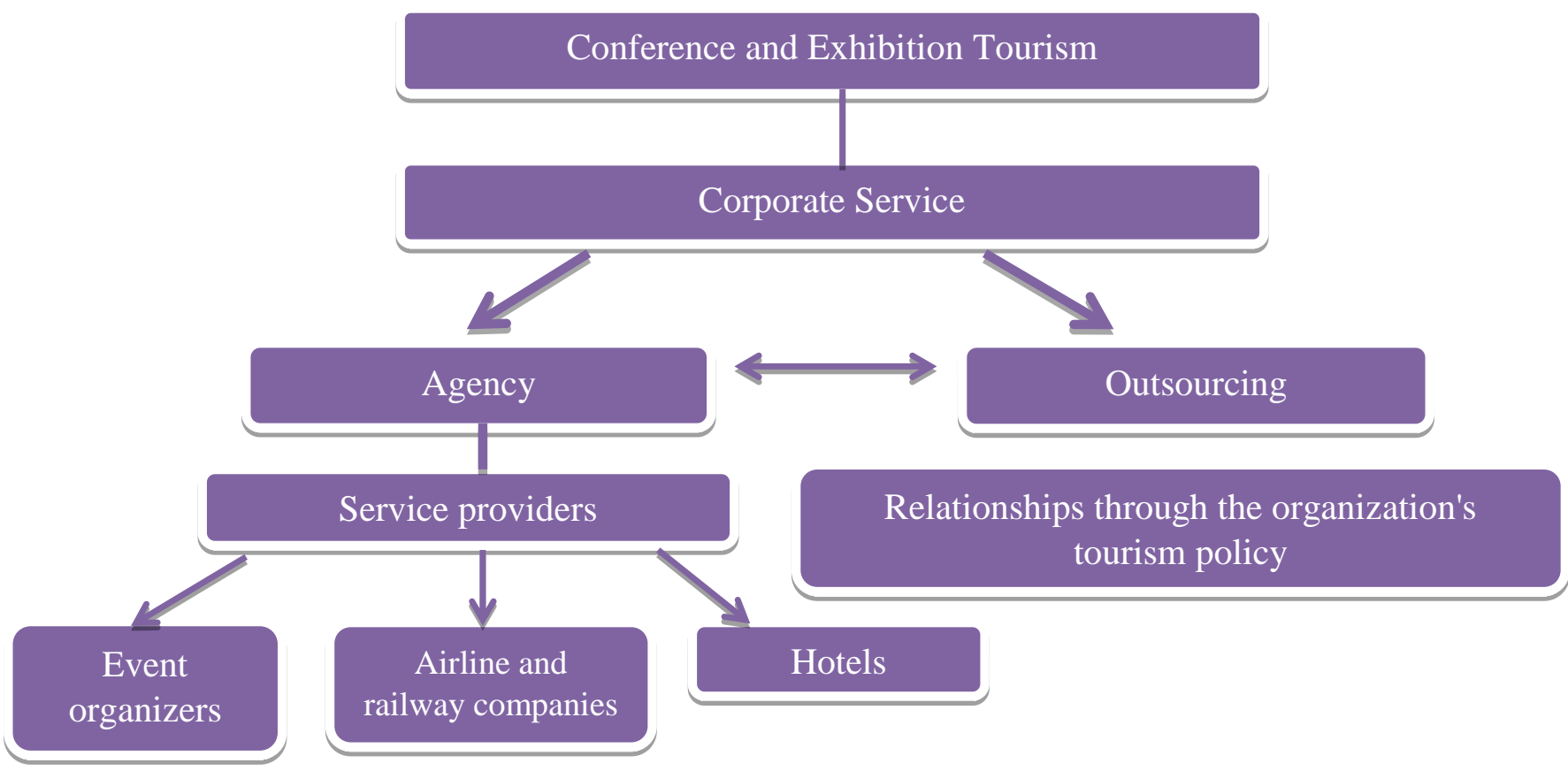

Consumers of conference and exhibition tourism services

Figure 1. Communication between travel partners and service providers in the outsourcing system* *Created by the author

MICE-tourism accounts for only about $7 \%$ of tourism activity worldwide. At the same time,
MICE tourists consume fewer resources, spend more money and often extend their 
stays for shopping or entertainment purposes. Such tourists also have a positive effect on the economy of the host country. The exchange of information and knowledge leads to the improvement of the business industry, the establishment of direct partnerships between market participants, and the research environment also improves and additional jobs are created for personnel (Figure 2).

The main difference between business tourism and individual travel is the higher price level. The purpose of such trips is to impress partners, clients and other participants, and the company's profit often depends on the success of the trip. As the demand for meetings, motivational tours, congresses and exhibitions grows, the future of the MICE sector is expected to be promising. However, with the development and high popularization of the MICE tourism industry, various difficulties and obstacles arise. Further will be considered the main problems that agencies face in organizing their work and providing services to tourists in Uzbekistan.

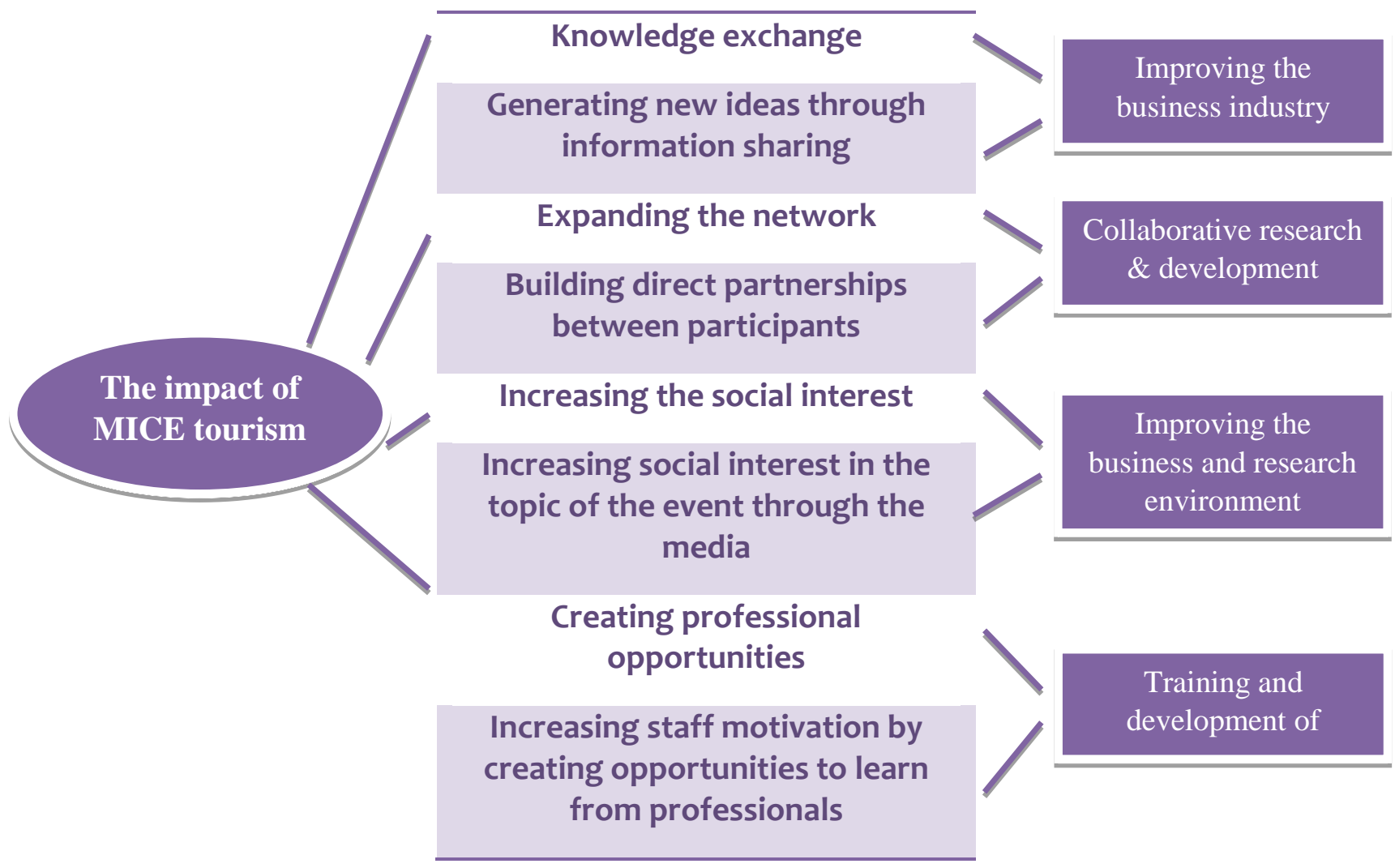

Figure 2. Impact of MICE tourism on the host country*

*Created by the author

A well-established infrastructure is a basic requirement when planning MICE events. The meeting place is considered a critical infrastructure element. Transport accessibility, quality of hotel services and technical equipment are the components that make up the competitive advantage of one location over another. Conference centers, fair and 
exhibition spaces can act as the main venue for the event.

Due to the fact that the meeting is a direct motive for this type of tourism activity, the capacity and quality of such facilities are taken into account first of all. Today, the city of Tashkent possesses a sufficient number of infrastructure facilities for receiving and servicing MICE tourists (Table 1), but the situation is different in regional centers. Conference rooms in the largest hotels in Bukhara, for example, can accommodate no more than 300 people at a time, and in Samarkand, an average of 100 to 150 people can be accommodated. Therefore, the capacity of objects is becoming a significant limitation for specialized travel agencies that plan to organize large MICE events in the regions of the republic.

Moreover, today the regions are significantly inferior to the capital in terms of availability of the necessary professional hardware. To organize a briefing, conference or seminar with the participation of a large number of foreigner guests, high-quality equipment is required. Agencies may need equipment for displaying information from several image sources, managing graphic materials, accompanying audio information with simultaneous translation, as well as audio sources.

Table 1. Capacity of Meeting Rooms \& Conference Halls in Tashkent*

\begin{tabular}{|c|c|c|c|}
\hline Hotel name & Available & Capacity & Arrangements \\
\hline $\begin{array}{l}\text { Hyatt Regency } \\
\text { Tashkent }\end{array}$ & $\begin{array}{l}3 \text { conference halls, } \\
\text { meeting rooms and } \\
\text { cocktail lounges }\end{array}$ & 12-700 people & $\begin{array}{c}\text { Theater, U- } \\
\text { shaped, Cocktail, } \\
\text { Class }\end{array}$ \\
\hline $\begin{array}{c}\text { International } \\
\text { Hotel Tashkent }\end{array}$ & $\begin{array}{l}6 \text { conference halls, } \\
\text { meeting rooms and } \\
\text { cocktail lounges }\end{array}$ & 25-500 people & $\begin{array}{c}\text { Theater, U- } \\
\text { shaped, Cocktail, } \\
\text { Class }\end{array}$ \\
\hline $\begin{array}{c}\text { Radisson Blu } \\
\text { Hotel }\end{array}$ & $\begin{array}{c}2 \text { conference halls, } 1 \\
\text { banquet hall }\end{array}$ & 25-250 people & $\begin{array}{c}\text { Theater, U- } \\
\text { shaped, Cocktail, } \\
\text { Class }\end{array}$ \\
\hline Wyndham & $\begin{array}{c}3 \text { conference halls, } 3 \\
\text { mini conference } \\
\text { rooms }\end{array}$ & 10-500 people & $\begin{array}{c}\text { Theater, U- } \\
\text { shaped, Cocktail, } \\
\text { Class }\end{array}$ \\
\hline Miran & $\begin{array}{l}3 \text { conference halls, } 3 \\
\text { mini conference } \\
\text { rooms }\end{array}$ & 25-600 people & $\begin{array}{l}\text { Theater, U- } \\
\text { shaped, Class, } \\
\text { Roundtable }\end{array}$ \\
\hline
\end{tabular}

* Created by the author

with the most affordable prices and proximity

MICE tourists have high requirements for a service company. This applies both to the type of services expected and to their quality. The duration of their stay is generally one or more days, depending on the duration of the event. Due to the limited time, such clients must be provided with the most comfortable living conditions, access to catering establishments to the meeting point, train station or airport. However, in our country this is not always possible due to seasonal fluctuations in the demand for travel services. Most respondents

and agency representatives face this problem during the high season. The increased demand 
for tourism and catering services, the lack of places in accommodation facilities, as well as non-availability of special constructions for the events, such as conference centers, exhibition and concert halls, historical buildings are becoming a significant obstacle to quality reception and guest service.

\section{CONCLUSIONS AND RECCOMENDATION}

The MICE sector provides great benefits not only to professional travel agencies, but also to the service companies involved. Such services, for example, include catering companies that provide contract catering services for participants and guests of events. The unsatisfactory quality of such services often not only disappoints MICE agents, but also negatively affects the reputation of the entire catering industry. Problems with catering at banquets and buffets and providing lunch boxes are most acutely felt. Improving the quality of services in this area would allow MICE agencies to turn to catering companies more often, thereby stimulating their further development.

In recent years, the MICE tourism sector in Uzbekistan has shown significant and intense growth. This is primarily due to the high return on good organization of events. To maintain such positive dynamics, it is necessary for all representatives of the hospitality to pay great attention to the existing problems of the industry and to actively participate in their solution.

\section{REFERENCES}

1. Sayyora Safaeva. Event tourism perspective form of tourism development in Uzbekistan. KIMEP International Research Conference: The Silk Road and the tourism and Hospitality Industries. 2018. pp. 62-64.

2. Safaeva, Sayyora Rikhsibaevna et al. Organizational and Economic Aspects of the Development of the International Tourism and Hospitality
Industry. Journal of Environmental Management and Tourism, [S.I.], v. 11, n. 4, p. 913-919, june 2020. ISSN 20687729. doi:https://doi.org/10.14505//jemt.11.4( 44).15.

3. Safaeva, S.R., Ishankhodjaeva, D.A., and other. 2019. Economic and Legal Aspects of Tourism Regulation in the New Economy: International Practice. Journal of Environmental Management and Tourism, 2(34): 460 465.

4. http://schedule.edu.pl/research/possibi lities-and-limitations-of-mice/

5. https://www.cbi.eu/marketinformation/tourism/mice-tourism

6. https://www.eunwto.org/doi/pdf/10.18111/9789284411 955

7. Rudskaya, E.N. Business tourism: problems, trends, prospects / E. N. Rudskaya, A. A. Skabarova // Young scientist. - 2015. - No. 8. - P. 639-646.

8. Davidson, R. Business Travel: Conferences, Incentive Travel, Exhibitions, Corporate Hospitality and Corporate Travel / R. Davidson, B. Cope. London, United Kingdom : Financial Times, 2002. P.:304.

9. Suvaryan Arzik M., Saakyan Maria A. and Antamoshkina Elena N. Business Tourism as a Promising Area on the Armenian and Russian Travel Service Market. Tourism: Law and Economics $3 \quad$ (66) $2018 . \quad$ P.11-16. searchgate.net/publication/328134896 _Delovoj_turizm_kak_perspektivnoe_ napravlenie_na_rynke_turistskih_uslu g_Armenii_i_Rossii/link̄/5bba68oā4585 159e8d8bd94f/download 